\title{
A FEW NEW NORTH AMERICAN NEUROPTERA
}

\author{
By NATHAN BANKS \\ Museum of Comparative Zoölogy, Harvard University
}

In the course of determinations the following species have been detected and described as new.

Psammoleon arizonensis sp. nov.

In general similar to P. sinuatus, but smaller and separated by the marks of head, and the two dark marks on wings are not connected. In $P$. sinuatus the front edge of vertex is marked by a row of four distinct spots or scars, in this new species the median two scars are united into a large dark brown diamond-shaped mark; on the middle of vertex behind in arizonensis is a pair of small pale spots which in sinuatus are black spots united to the second vertex band. The pronotum shows, more or less plainly, the pale median line and two pale spots each side. The abdomen shows two pale above on each segment. The tarsi and claws are similar to $\mathrm{P}$. sinuatus. The wings show the two oblique dark marks about as oblique as in sinuatus, but no connecting mark; the hind wings have a dark cloud on hind margin as in $P$. sinuatus.

Fore wings $26 \mathrm{~mm}$. long, $5 \mathrm{~mm}$. wide. Hind wings 24 $\mathrm{mm}$. long, $4 \mathrm{~mm}$. wide.

From Phoenix, 10, June; and Tucson, Arizona 25, July. (Streets collr.). Type M. C. Z. no. 20119.

Psammoleon decipiens sp. nov.

In general very similar to $P$. guttipes. Readily separated therefrom by the marks of the head. Above the interantennal mark is a transverse pale band above which is a velvety dark brown band from eye to eye, broader in middle, behind this on vertex another transverse pale band, and behind this another dark band (in guttipes the dark of interantennal mark extends up to the transverse row of four 
pale scars). The forewings have the usual two oblique dark streaks, the first concave toward base and before each of these marks there is a large area of wholly white venation, much larger than in $P$. guttipes. The venation is very similar to $P$. guttipes but in fore wings the costal area is less broad and the costal crossveins less numerous, so that the costal cells are not nearly as narrow as in P. guttipes.

Size as in P. guttipes. From Millin, Scriven Co., Georgia, and Shreveport, Louisiana. Type M. C. Z. no. 20118.

Psammoleon parallela sp. nov.

Face yellowish, a large black interantennal mark, vertex dark, two black lines across the ridges from eye to eye, last joint of labial palpi moderately dark, not greatly enlarged; antennæ annulate with brown; pronotum dark, a few faint pale marks, a rather large one each side; mesoand metanotum dark, a few pale spots or streaks, mostly through middle; pleura mostly pale, a few brown marks above, with long white hair; abdomen dull black, three pale spots above on each segment, a median one before middle, and one each side toward tip, with very short white hair above, longer below toward base. Legs pale, black spots on femora, mostly above, near base and tip of tibia, and some between, tips of tarsal joints black. Wings not very clear; veins pale, marked with black mostly in streaks, many cross-veins wholly dark, especially toward tip and behind, costals dark at each end; stigma yellowish, blackish basally; a dark streak obliquely up from end of anal and cubital fork, another oblique dark streak at rhegma, on several cross-veins; hind wings with veins mostly pale, and the dark not so black. Wings rather more narrow than usual, not widened near stigma, tip rounded; seven cross-veins before radial sector in fore wing, one in hind wing; ten branches to radial sector in fore wing, nine in hind wing; six cross-veins before cubital fork in fore wing, the anal runs nearly parallel to the cubital fork for a greater distance than in other species, and connected to each other by seven to nine cross-veins ; in hind wing at most one cross-vein between cubital fork and first anal vein, often none.

Length of body, $20 \mathrm{~mm}$. Length of forewing, $25 \mathrm{~mm}$, 
width $5.2 \mathrm{~mm}$. Length of hind wing, $25 \mathrm{~mm}$., width 4.5 $\mathrm{mm}$.

From Puerto Castillo, Honduras, (J. Bequaert); and Puntarenas, Costa Rica, 11-1907 P. Biolley, Philad. Acad. Nat. Science. Type M. C. Z. no. 20117.

Chrysopiella minora sp. nov.

Pale yellowish. Face with a brown stripe on each cheek down to the clypeus and there an inner extension; palpi marked with dark; no spot below bases of antennae, and no brown on lower sides of basal joints, but a stripe of brown on outer side of each basal joint, second joint dark brown, beyond the antennae are slightly dark. On front of vertex back of antennae is a fine curved dark line and on top of vertex two short dark stripes. Pronotum and rest of thorax unmarked, as well as legs. Wings with wholly pale venation, stigma more greenish. Wings very slender, more so than in other species, only eight radial cross-veins, only three or four in outer gradate series, the last of these not its length from margin, third cubital cell long, the divisory vein starting from middle of base of cell and ending beyond the end of the cross-vein above; twelve to thirteen costals before stigma.

Length of forewing $8 \mathrm{~mm}$., width $2.7 \mathrm{~mm}$.

Umatilla, Oregon, 24 June, 1882 (S. Henshaw). Smaller and lacks dark marks of the face of other species. Type M. C. Z. 19439.

Boriomyia furcata sp. nov.

In my table (Psyche 1930, 224) runs to 11 , but smaller than either and with quite different male genitalia. Face shining brown; basal joints of antennae dark, beyond pale, scarcely annulate; vertex dark, with a median darker line; pronotum with broad dark side margins and narrow median line, rest of thorax mostly dark but with sutures pale; legs pale, base and tips of front and mid tibiæ dark; abdomen dark above, pale below, above with erect pale yellowish hair, most prominent near tip. Forewings rather heavily marked with brown, tending to form many bands, more distinct over the first gradate series; veins dotted and spotted with dark and white. 
Wings of moderate length and breadth; cross-vein between first radial sector and median vein is beyond fork of median, no cross-vein between first and second radial sectors near their bases, one between last radial sector and radius, that between median and cubitus is longer than that between cubitus and its fork; the first gradate series (of 6 or 7) form a nearly even series across, but very little disjointed, and less oblique than in related species. The male appendages are deeply forked.

Length forewing $8 \mathrm{~mm}$., width $3 \mathrm{~mm}$.

From Argentine Pass, Colo. (Cockerell). Type M. C. Z. 19436.

Allotomyia borealis sp. nov.

Pale yellowish; in the male the face is shining black, in the female with a transverse spot below antennae; pronotum dark on sides; mesonotum and metanotum dark above base of wings; abdomen brown; forewings marked with dark at the gradate series, and some spots toward base, and with marginal brown spaces alternating with white spaces; many of the veins with dark dots; hind wings wholly pale, without marks. Venation much as in $A$. $f$ delis; no cross-vein from last radial sector to radius, one from first radial sector to second near its base, and a little before the cross-vein from the first radial sector to the median vein; first series of gradates further out than in $A$. fidelis, as near to second series at these to the outer margin. Male genitalia very different from $A$. fidelis; seen from the side extremely broad toward base.

Length of forewing $8 \mathrm{~mm}$.

A male from Hillsboro, N. H., 12 June. A female taken by Mrs. Slosson many years ago at Franconia, N. H. agrees in the markings of the wings. Type M. C. Z. 19437.

Megalomus uniformis sp. nov.

Body, antennae, and legs pale yellowish, unmarked; wings the same, but the gradate series are narrowly brown, and a dot on the connection of cubitus and median, and faint brown borders of apical forkings; the dark dots seen on the veins of other species are here practically absent; hind wings slightly embrowned around margin. Costal area 
very broad at base, broader than in $M$. moestus, about as broad as $M$. latus, some of the costal veinlets toward base are forked twice; four cross-veins between the sub-costa and radius, one at base, two between the second and third radial sectors, and one near the stigma; seven radial sectors; first series of gradates further out than in other species, evenly oblique (not broken) and formed of thirteen cross-veins before it ends in a hyaline spot at hind margin; outer gradate series of ten cross veins, forming only a slight curve, and nearer to the first row than in allied species.

Length of forewing $7 \mathrm{~mm}$.

From Brownsville, Tex. (Snow coll.) Type M. C. Z. 19438. 

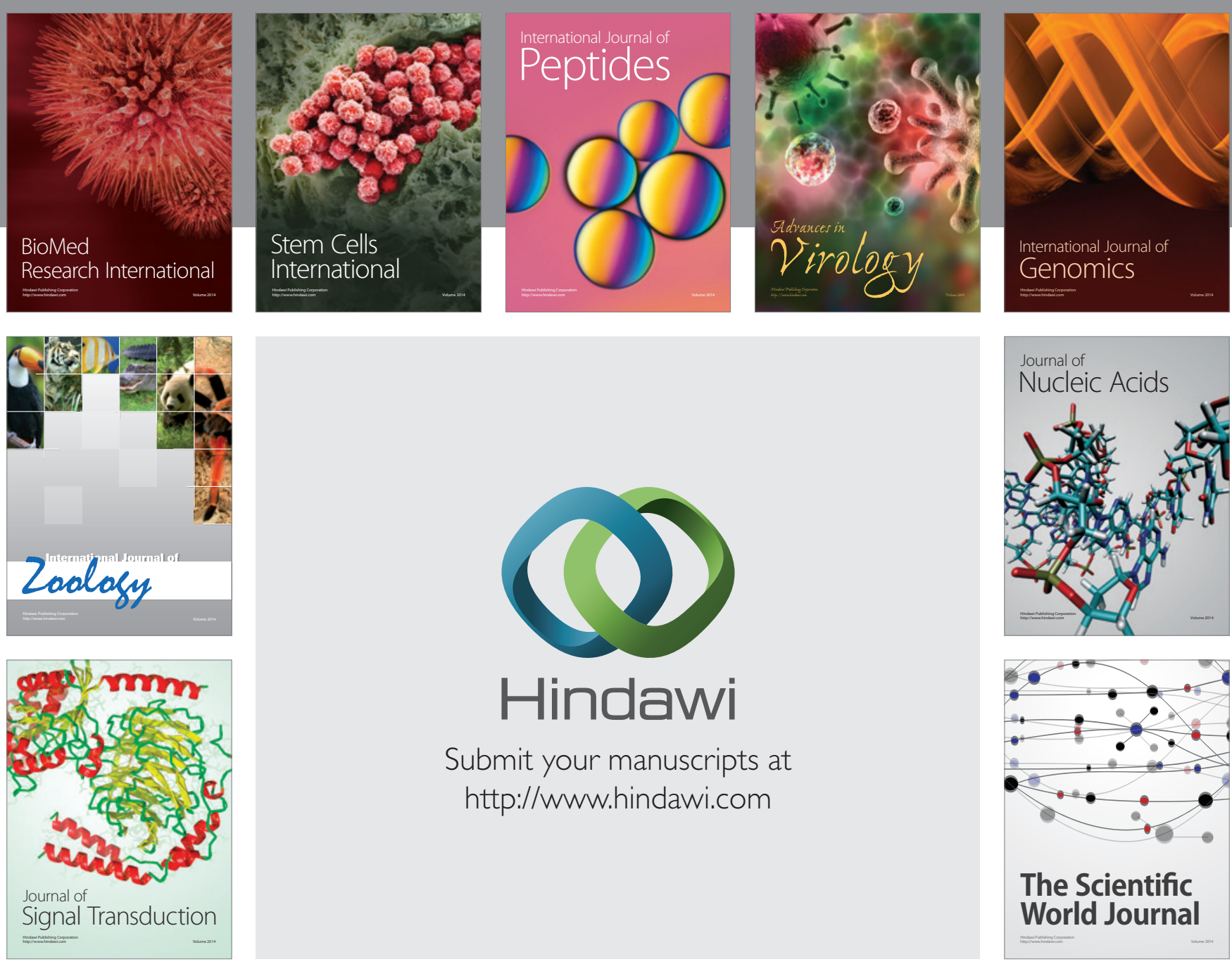

Submit your manuscripts at

http://www.hindawi.com
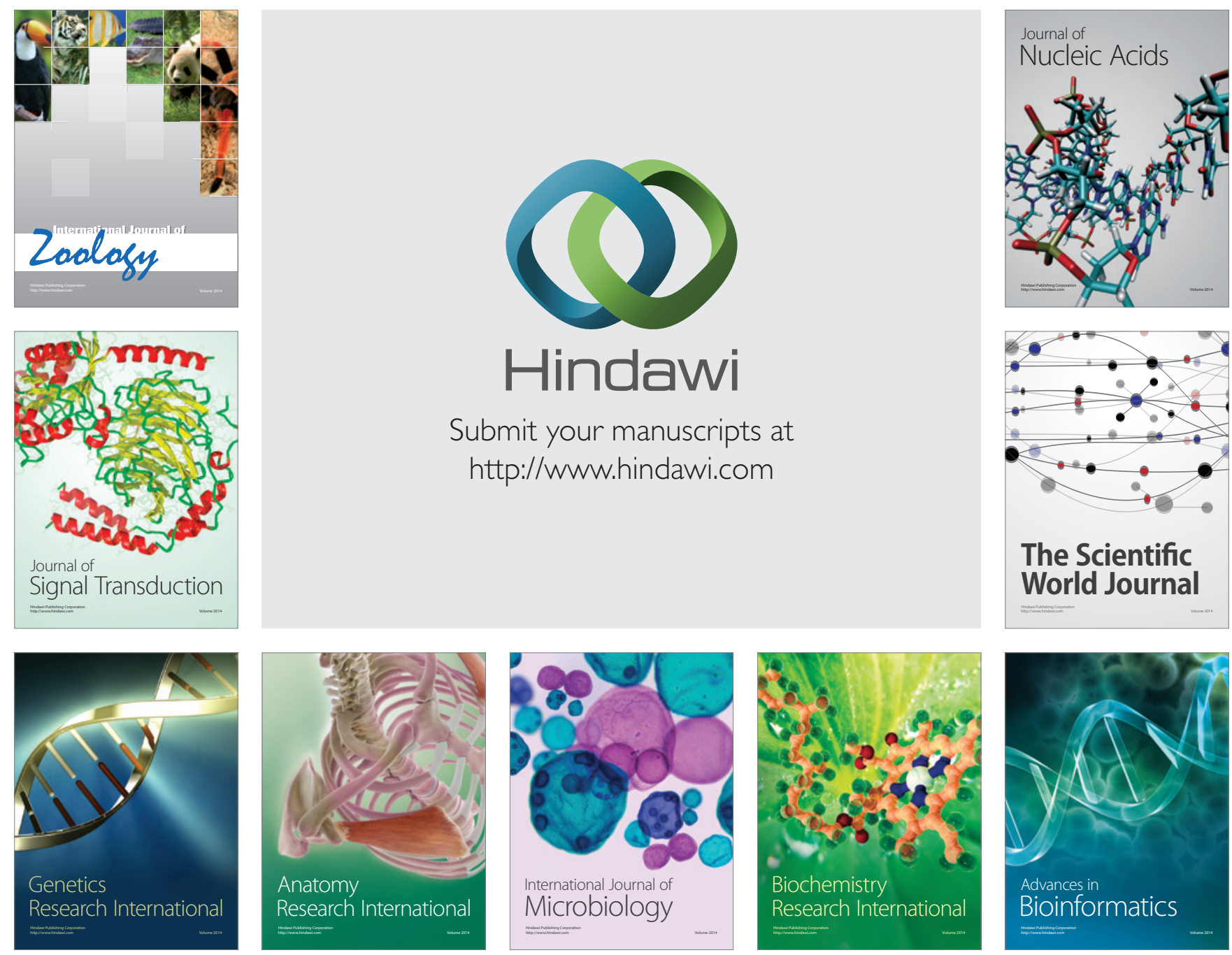

The Scientific World Journal
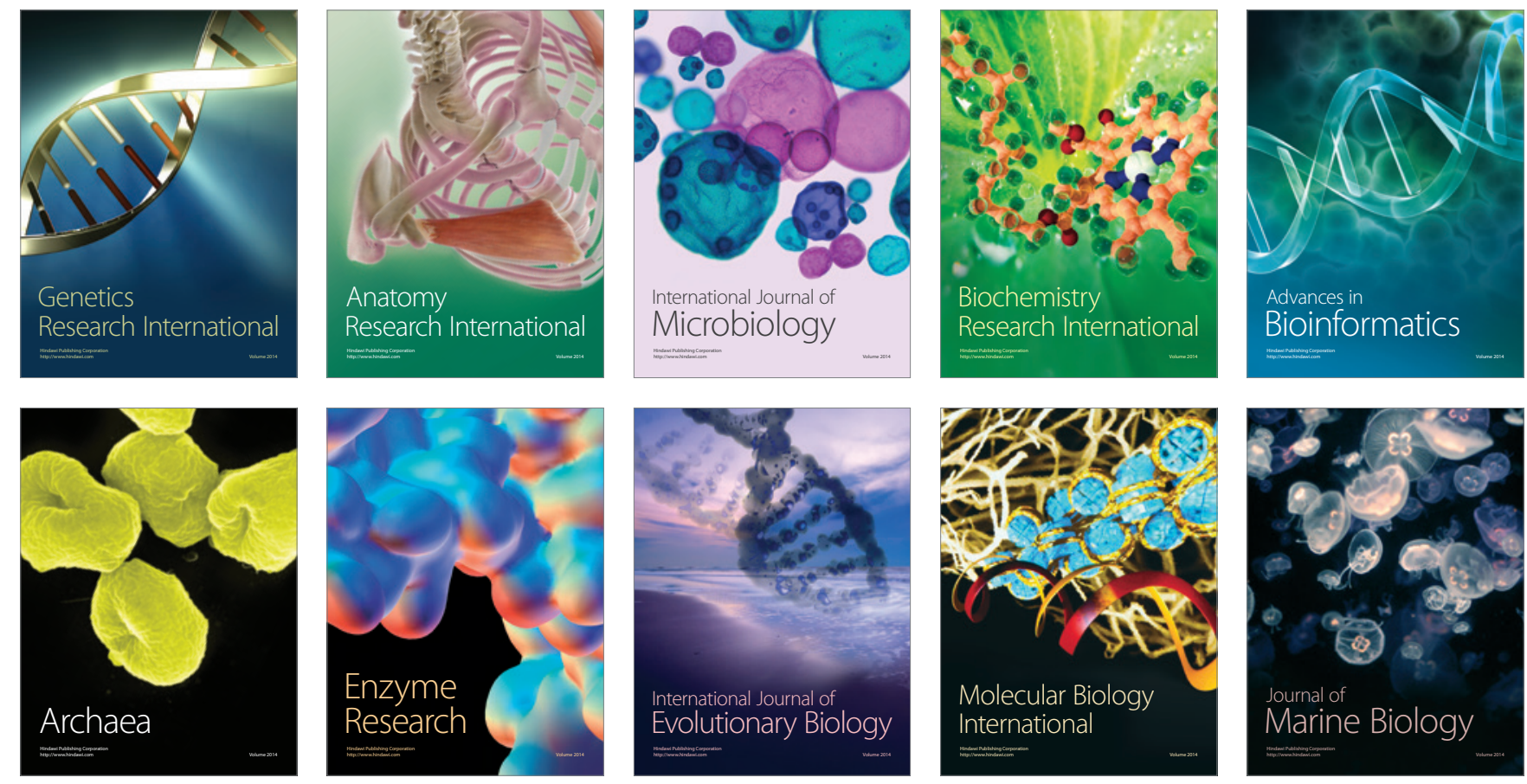